NBER WORKING PAPER SERIES

\title{
PLATFORM OWNER ENTRY AND INNOVATION IN COMPLEMENTARY MARKETS: \\ EVIDENCE FROM INTEL
}

\author{
Annabelle Gawer \\ Rebecca Henderson \\ Working Paper 11852 \\ http://www.nber.org/papers/w11852

\section{NATIONAL BUREAU OF ECONOMIC RESEARCH 1050 Massachusetts Avenue \\ Cambridge, MA 02138} \\ December 2005
}

The authors would like to thank Barry Nalebuff, Michael Cusumano, Scott Stern, David Gann, the participants at the Stanford Strategy Conference and two reviewers who provided valuable suggestions. Thanks also go to the many Intel managers who agreed to be interviewed. The usual disclaimers apply.The views expressed herein are those of the author(s) and do not necessarily reflect the views of the National Bureau of Economic Research.

(C2005 by Annabelle Gawer and Rebecca Henderson. All rights reserved. Short sections of text, not to exceed two paragraphs, may be quoted without explicit permission provided that full credit, including () notice, is given to the source. 
Platform Owner Entry and Innovation in Complementary Markets: Evidence from Intel Annabelle Gawer and Rebecca Henderson

NBER Working Paper No. 11852

December 2005

JEL No. L0

\begin{abstract}
$\underline{\text { ABSTRACT }}$
This paper draws on a detailed history of Intel's strategy with respect to the complementary markets for microprocessors to explore the usefulness of the current theoretical literature for explaining behavior. We find that as the literature predicts, Intel invests heavily in these markets, both through direct entry and through subsidy. We also find, again consistent with the literature, that the firm's entry decisions are shaped by the belief that it does not have either the capabilities or the resources to enter all possible markets, and thus that it believes it is critical to encourage widespread entry. As several authors have pointed out, this imperative places the firm in a difficult strategic position, since it needs to attempt to commit to potential entrants that it will not engage in an ex-post "squeeze", despite the fact that ex post it has very strong incentives to do so. We find that the fact that the complementary markets in which Intel competes are complex, dynamic and multilayered considerably sharpens this dilemma. We explore the ways in which Intel attempts to solve it, highlighting in particular the organizational structure and processes through which they attempt to commit to making money in the markets which they choose to enter while also committing not to making too much. Our results have implications for both our understanding of the dynamics of competition in complements and of the role of organizational structures and processes in shaping competition.

Annabelle Gawer

Imperial College London

Tanaka Business School

London, SW7 2 AZ, UK

a.gawer@imperial.ac.uk

Rebecca Henderson

Sloan School of Management

MIT, E52-543

50 Memorial Drive

Cambridge, MA 02142-1347

and NBER

rhenderson@mit.edu
\end{abstract}




\section{INTRODUCTION}

Many high -technology industries offer products or services which can be described as systems of interdependent components, built around or on top of "platforms". In these industrial "ecosystems", very large players may have considerable influence over the livelihood of developers of complementary products, and the behavior of platform owners towards the other firms in the ecosystem has been subject to much scrutiny. In particular, the recent landmark Microsoft antitrust trial has sparked considerable interest in the behavior of platform owners with respect to complementary markets, and in the consequences of platform owner entry for innovation.

Despite its importance, this is a surprisingly unexplored question. Existing theoretical models tend to focus quite narrowly on the individual factors that shape entry decisions. Few models have anything to say about how incentives may change in the case of a platform - and its corresponding complementary markets -- that are likely to evolve in ways that cannot be predicted. Moreover while some models suggest that entry in complementary markets is always optimal for a platform owner, others suggest that in some circumstances a platform owner's ability to commit not to enter complementary markets may be important to preserve complementors' incentives to innovate. ${ }^{1}$ There is also very scant empirical work in the area. To our knowledge there is no research that explores platform owner incentives systematically across a range of complementary markets, or that focuses on how some of the key drivers from the theoretical literature can be identified, on whether they are important, or on how they may trade-off against each other.

For example, while the literature hints at the idea that in those cases in which platform owners do not have the necessary organizational capabilities, they might wish to subsidize entry into complementary markets but to refrain credibly from entry themselves,

\footnotetext{
${ }^{1}$ We use the term "complementor" in the sense defined by Brandenburger and Nalebuff (1997), as a shorthand for "the developer of a complementary product" where two products are complements if greater sales of one increase demand for the other. Formally, A and B are complements if the valuation by consumers of $\mathrm{A}$ and $\mathrm{B}$ together is greater than the sum of the valuation of $\mathrm{A}$ alone and of $\mathrm{B}$ alone. $\mathrm{V}_{\mathrm{a}+\mathrm{b}}=(1$ $+\mathrm{d})\left(\mathrm{V}_{\mathrm{a}}+\mathrm{V}_{\mathrm{b}}\right), \mathrm{d}>0$ (Nalebuff, 2004).
} 
they give very little insight as to how this might be done. Moreover they offer no insight as to how platform owners should behave when the platform itself is dynamically evolving. Should they enter complementary markets to maintain control of the platform? Should they refrain? If they do enter, how can they maintain incentives for entrant innovation?

This paper explores these issues through the medium of a detailed study of Intel's experiences with complementary markets in the personal computer industry. Intel offers a particularly favorable setting for an in-depth case study of this question, because entry and innovation in complementary markets were a central and recurring problem for the firm: as the provider of an essential element of the personal computer, Intel's decision to enter complementary markets - or not -- strongly affected its relationship with external providers of complementary products, and was thus strategically important. Our data cover 14 years of entry decisions in a range of complementary markets, under different market conditions and under changing strategic contexts. We use them to analyze Intel's actions and avowed motivations, exploring the degree to which Intel's history confirms the usefulness of current theory and raises new questions for future work.

We find, as predicted, that Intel's behavior with respect to complementary markets is greatly shaped by whether the firm can match the competencies of potential entrants. But we also find that Intel's behavior is heavily influenced by whether the interface between markets is "static" (when the platform boundary is reasonably stable) or "dynamic" (when the scope of the platform and the ways in which it interacts with complementary products are changing). In those cases where the interface between markets is evolving Intel is much more likely to enter the "connector" markets - markets for those products that embody new platform interfaces. Since this then puts Intel in a particularly strong position to squeeze potential entrants in both the connector markets themselves and in complementary markets that are adjacent to, or "on top" of these markets, Intel experiences the dilemma outlined in the literature in a particularly acute form, and their desire to encourage innovation amongst entrants shapes the firm's behavior in some intriguing ways.

Intel appears to rely on three primary mechanisms to signal that it will not engage in any ex-post "squeezing" of entrants. First, it uses an internal organizational structure 
(separate divisions with their own Profit \& Loss operations) and a widely publicized rhetorical device (the distinction between "Job 1" and "Job 2"2) to signal that it expects both Intel and its competitors to make money in complementary markets - that it will not "suck all the air" out of them. Second, it attempts to subsidize entry into complementary markets not through direct subsidy but by lowering the cost of entry for all potential entrants largely, but not only, by the development and widespread dissemination of htellectual Property. Third, it attempts to commit to the stability and security of these subsidies - and, given its frequent entry into markets for interface technologies -- to the promise not to change "the rules of the game" in these markets through the creation of a separate organizational unit (The Intel Architecture Lab) which is explicitly structured as a cost center and rewarded for its success in "promoting the health of the ecosystem" as a whole, or for stimulating demand for microprocessors.

This combination of activities creates considerable tension inside the firm, since on the one hand managers within Intel are encouraged to profit maximize within complementary markets while on the other their colleagues are actively subsidizing the entry of competitors and publicly refusing to use Intel's control of the architecture to advantage internal divisions. Intel must make money in complementary markets - but not too much. We believe that these results - and the intriguing interplay they suggest between strategic interaction and organizational structure -- have potential implications for both theoretical work and further empirical research, and for both business strategy and public policy.

The rest of the article is structured as follows: Section 2 presents a short literature review, Section 3 the methods and data and Section 4 the results of the study. Section 5 presents a discussion of the results, clarifies the directions in which they extend existing literature, and offers some conclusions.

\section{Literature REVIEW}

We focus our theoretical discussion and our empirical research around "platforms", where we define a product as a "platform" when it is one component or subsystem of an

\footnotetext{
2 "Job 1" refers to the task of expanding demand for the microprocessor, whereas "Job 2" refers to the task of growing profitable businesses in complementary markets .
} 
evolving technological system, when it is strongly functionally interdependent with most of the other components of this system, and when end-user demand is for the overall system, so that there is no demand for components when they are isolated from the overall system. ${ }^{3}$ We define a platform "owner" as a firm that owns a core element of the technological system that defines its forward evolution. In this sense both Intel and Microsoft are platform "owners".

From this perspective, the relationship between a platform owner and other firms who are actual or potential owners of other components of the system is well modeled as that between an incumbent monopolist and actual or potential competitors in other, complementary markets, since demand for the platform is derived from the demand for the overall system.

However the literature exploring a monopolist's incentive to enter the market for complements is subtle and complex, and one can draw no quick conclusion as to whether a monopolist will choose to enter complementary markets or as to whether such entry will enhance or reduce social welfare.

Work focusing on the multiproduct problem and on bundling (see for example work by Schmalensee, 1981; Panzar, 1989; Whinston, 1990, Nalebuff, 2004) has examined entry in complementary markets, but without paying particular attention to platform dynamics or network effects. By and large, these authors suggest that monopolists have several strong reasons for entering complementary markets in order to offer a bundle or a tie. Most critical, of course, is that identified initially by Cournot (1838). Multiproduct firms - those producing both products, in the case of two complementary markets - internalize the demand externality across markets while single product firms do not, so that in the simple case both consumer welfare and total profits are increased if both products are produced by a single firm. Firms may also enter multiple markets to weaken rivals through price competition, driving the price of the complement down and raising the price of the

\footnotetext{
${ }^{3}$ Our definition therefore differs from the definition of "platform" current in the multi-sided market literature (e.g., Rochet and Tirole, 2003, 2004) which includes realestate agencies, or dating bars - as these assume that the complementary markets are pre-defined, well-known, and that the platform scope is static. Our definition is closer to the one of Bresnahan and Greenstein (1999) who define a platform as a bundle of standard components around which buyers and sellers coordinate efforts, or West (2003) who defines it an architecture of related standards, allowing modular substitution of complementary assets such as software and peripheral hardware-but we do not require components to be "standards".
} 
essential good to capture the available rent (Ordover et al., 1985). This may or may not be predatory or exclusionary: it depends on how much the monopolist "squeezes" the complementors since a price squeeze induces complementors to offer as much surplus as possible in the complementary market (Whinston, 1990; Nalebuff, 2004). However these models ignore the effect of entry on complementors' incentives to innovate.

The related multi-sided market (MSM) work stream (Rochet and Tirole, 2003, 2004; Caillaud and Jullien, 2003; Hagiu, 2004) focuses on the pricing problem faced by platform owners in two-sided markets when they aim to encourage adoption of the platform. More recently, Hagiu (2005) explores the effect of platform pricing on complementors' innovation incentives, but focuses exclusively on the platform owners' choice between charging complementors fixed fees or variable fees (royalties), to find the optimal royalty rate. The main insight of this stream of work is that two-sided platform owners will subsidize one "side" of the platform (e.g., complementors) in order to create or jumpstart a double-sided market. It thus follows the same logic as the "internalize-theexternalities" argument of the multi-product/bundling literature but focuses on subsidy rather than on entry as the central mechanism through which it can be accomplished.

Recent work has focused on the effects of entry in complementary markets on complementors' incentives to innovate. Choi and Stefanadis (2001) show that with uncertain investment, a monopolist's entry in complementary market results in a potential price squeeze that may deter innovation by rivals. Heeb (2003) also confirms that price squeezes may deter complementary innovation.

Three recent papers enable us to refine our understanding of entry's incentives in the particular case when platform owner's capabilities are not equivalent to those of entrants (Farrell and Katz, 2000; Becchetti and Paganetto, 2001; Miller, 2005). These papers suggest that when an incumbent monopolist lacks the organizational capabilities of potential thirdparty complementors it will have an incentive to encourage third-party innovation, but that the if the monopolist's incentive to engage in ex-post price "squeezes" is sufficiently strong, entrants may have no ex-ante incentive to engage in innovation at all. This work suggests that if the monopolist cannot duplicate the entrants' innovation at a reasonable cost, then it may have strong incentives to try to commit to entrants that it will not enter 
the market for complements as a way to encourage the competitive efforts of independent suppliers of the complementary product. The difficulty is that, even if the overall ex-ante effects of a squeeze are negative for the monopolist, it may be difficult for him to commit not to engage in one ex post, particularly if he is already integrated into the supply of other complementary products. Taken together, these papers warn of the possible adverse effects of integration into complementary markets on incentives to innovate for complementors.

Of course there are other - well-known - reasons why a platform owner might not want to enter complementary markets. They might already be fully competitive. They might have too small an impact on platform demand to be worth the effort, or entry might be more effort than it is worth. A monopolist might be capital constrain ed or might fear retaliation from powerful competitors. ${ }^{4}$

Intriguingly, none of these models considers the case in which the interface between complementary markets may be evolving. In the few articles that do consider platform evolution, the consequences for the players' incentives to innovate are ambiguous. Farrell et al. (1998) can be interpreted as suggesting that when interfaces are likely to evolve such that a platform owner is likely to lose control of the architecture, the platform owner should integrate into the interface. Similarly Carlton and Waldman (2002) suggest that strategic tie-ins to evolving complementary markets may be a way to extend monopoly power into a newly emerging market. Both models would seem to suggest that in these cases innovation in complementary markets is likely to be suppressed. But Davis et al. (2002) suggest that Microsoft's entry into complementary markets, followed by product

\footnotetext{
${ }^{4}$ In 1996 Intel attempted to extend its platform into Microsoft's territory, through the development of "Native Signal Processing," which allowed much of the manipulation of audio and video traditionally carried out on specialized chips on the computer's motherboard to be built into the microprocessor itself. Jackson (1997) reports: “In principle, NSP was in both companies' interest. The problem was that the NSP technology Intel had developed didn't slot into DOS or Windows. It stood alone, and by doing so, it appeared to challenge Microsoft's hegemony over software standards. The reaction from Microsoft was swift and vicious. Without saying anything to Intel, Microsoft warned the PC manufacturers that it had no intention of supporting NSP in future releases of Windows, effectively forcing them to sacrifice 100 percent compatibility with Microsoft's standards if they went along with Intel's initiative." Intel later halted its NSP investments.
} 
integration, facilitated the development of new applications. ${ }^{5}$ Closest to our own approach, West and Dedrick (2000)'s and West (2003)'s case studies suggest that the treatment of intellectual property (whether the platforms are "open" or "proprietary"), as well as the availability of appropriate development tools affects the platform owners' ability to control the evolution of the platform architecture, and the likelihood of innovation in complementary markets.

Taken together, these articles suggest that it is generally in the interest of a platform owner to enter complementary markets, but that such entry must be balanced against the costs of discouraging entry by new firms. However the existing literature offers us no guidance as to how this tradeoff should be managed and no evidence as to how - or whether -- it is being managed in practice. How do incentives to enter in order to internalize externalities trade off against the need to encourage entry when the relevant organizational capabilities are scarce or unavailable? How does a platform owner commit to not entering a market when, once that market is established it will have a strong incentive to do just that? In the dynamic case, if the platform owner has strong incentives to enter to control the evolution of a platform, how does this shape action? How does it shape complementors' behavior? Will it be seen as exactly the kind of ex-post squeeze that other models suggest may be very destructive? How can one distinguish, empirically, between entry to control platform direction, and entry to internalize externalities? Is it useful to draw a distinction between them?

Our paper contributes to this debate by allowing us to distinguish between the different drivers of entry into complementary markets, by exploring the degree to which Intel balances it own strong incentives to enter against the risk of discouraging complementors' innovation, and by highlighting the significance of the organizational structure and processes of the firm in enabling Intel to manage these tradeoffs.

\footnotetext{
${ }^{5}$ Davis et al. (2002) claim that integration in complementary markets reduces the cost of complementors' innovation. They do not however balance this effect with the potential entry deterrence effect. They point principally to the release of Application Programming Interfaces ("APIs" - software tools that allow complementors to develop complementary applications that will interoperate smoothly with the platform) to facilitate complementary innovation.
} 


\section{DATA AND METHODS}

We draw on extensive qualitative data drawn from Intel's recent history to explore these issues. Intel offers a particularly favorable setting for an in-depth case study of our central question for several reasons. First, entry and innovation in complementary markets were a central and recurring strategic problem for the firm. As the provider of an essential element of the personal computer, Intel's choices of entry in complementary markets strongly affected its relationship with external providers of complementary products. Second, as the largest global producer of microprocessors between 1990 and 2004, Intel was clearly a platform owner, and plausibly had considerable market power for most of the period. ${ }^{6}$ Intel also changed strategic focus twice between 1990 and 2004. The period thus allows us to explain a wide spectrum of Intel's behaviors vis-à-vis complementors.

Our data covers the period 1990 to 2004. The empirical analysis draws on a sequence of 72 in-depth qualitative interviews conducted with senior managers at Intel, as well as on primary and secondary literature. We gathered data on 27 projects, which between them constituted what we believe to be all the projects and initiatives that Intel undertook - or considered undertaking - between 1990 and 2004 that had effects on complementors and complementary markets. The complete list of these projects is given in Appendix Table I.

We conducted nterviews during three visits to Intel to sites in both California and Oregon between November 1997 and April 2000. We explained to our respondents that we were doing a study of the ways in which Intel had attempted to have an effect on innovation in "complementary products", i.e., products whose supply could have a demand-enhancing effect on the microprocessor. The interviews were semi-structured (that is, respondents were provided with a list of interview questions beforehand, but were not held to them as the interview progressed). Most interviews lasted about an hour, although some lasted much longer. All the interviews were taped and transcribed. The initial interviews covered a broad range of topics, including company history and structure, industry innovation and competition, the relationships between Intel and other

\footnotetext{
${ }^{6}$ Between 1991 and 2000, Intel revenue increased from $\$ 4.8$ billion to $\$ 33.7$ billion, wh ile profits grew from $\$ 819$ million to $\$ 10.5$ billion over the same period. Return on assets over the period averaged around $25 \%$. However, like every technology company, Intel was hit hard by the burst of the Internet bubble. Revenues for 2001 were $\$ 26.5$ billion, while net income for 2001 only \$1.3 billion. In 2003 however, Intel posted revenue of $\$ 30.1$ billion and net income of $\$ 5.6$ billion.
} 
firms, customers, suppliers, and complementors. Later interviews focused on the history of the many facets of Intel's involvement in innovation in complementary products, and went deeper into the managerial processes by which Intel attempted to influence innovation. We were also given access to a wide range of internal documents, including organization charts, company brochures, project planning documents, internal presentations documents and project information, and we were invited to attend several internal company meetings.

The use of a qualitative approach has both advantages and limitations. Comprehensive studies of firm decision-making that focus on economically significant decisions are rare. Given that it is difficult to measure the extent to which several variables affect entry decisions in particular markets, systematic qualitative data about organizational process, structure and internal beliefs provide an important alternative source of evidence. During the course of our research we took a number of measures to ensure that as far as possible we were not simply hearing the "party line" from our informants. We describe these in more detail below. In consequence, we believe that our results accurately describe the beliefs of Intel's senior and middle management, and that these beliefs had important effects on Intel's actions.

In an attempt both to avoid problems of retrospective bias and also in order to avoid being given "official propaganda", we interviewed managers at several different levels of seniority, including senior officers, team leaders, engineers and marketers. One set of interviewees was approached through initial contacts with the managers of the Intel Architecture Lab. Another set of interviewees came from an initial contact with a member of the board of directors of Intel, who arranged for interviews with Intel's top management team. The final set of interviewees was derived from recommendations from the first two. The gradual accretion of interviewees allowed the reach of the interviews to move well beyond the initial group of IAL personnel and top managers. Interviews were conducted in 11 different functional groups and at 5 different sites. Most of the interviewees had a long tenure at Intel and had worked in several groups throughout their career. At the end of each interview, each interviewee was asked to suggest names of other employees who might be able to confirm the interviewer's own account or who might be able to provide a contrasting perspective. One of the reasons that we believe these interviews to reflect the 
genuine beliefs of Intel managers is that we often uncovered conflicts between different managers, different groups, and different hierarchical levels. This suggested to us that we were not being given a "party line" but were gaining a true sense for the basis on which key strategic decisions had been made within the firm. Further details can be found in Gawer (2000).

In the analysis below, we attempt to summarize the interviews, and the understanding of Intel's strategy and beliefs that we gained as a result of conducting them, through the use of brief quotations. We have endeavored to ensure that the quotes are representative in that they catch the sense of a number of interviews and the perspectives of a number of different managers.

\section{Results}

One of the most striking findings from the interviews is that of Intel's strategic sophistication with respect to the dynamics of the markets for complements. It is clear, first, that Intel understands the importance of generating complements to the success of their microprocessor business. Gerald Holzhammer - the director of the Intel Architecture Lab in 1997 and the director of the desktop architecture lab from 1998 on - described the decision to focus on software in an attempt to stimulate growth in demand for computers in terms that could have come directly from a textbook:

There was a master plan ... that said we need to encourage innovation on software applications. It all came about fairly naturally. . . If the end user doesn't see really immediate added value by buying the nextgeneration processor, then Intel will not grow. Intel will have a huge problem. We are spending billions of dollars building these new manufacturing plants. If people don't come, don't buy, we will fall off a cliff. That's the reason why we have an Intel Architecture Lab, whose fundamental mission is to grow the overall market. We need to amortize our manufacturing capacity in a large number of units. That will happen only if there are new applications. How do you grow a market? Intel has 80, 85, 90 percent market segment share for CPUs. You don't grow by getting another 2 percent. You grow by growing the entire pie. How do you grow your pie? By getting new applications, find new users for the PC. ${ }^{7}$

\footnotetext{
7 Interview with Gerald Holzhammer, then director of the Architecture Lab, Hillsboro, Oregon, Novermber 11, 1995. Emphasis added.
} 
Given this appreciation of the demand enhancing effect of activity in complementary markets it is perhaps not surprising that of the 27 cases in which we know that Intel actively considered entry, the firm actually entered 17 times, or $63 \%$ of the time. Moreover, consistent with the literature, there is some evidence that Intel's entry decisions were shaped by whether or not it believed that it possessed the requisite capabilities. For example, Claude Leglise, director of the Developer Relations Group, insisted:

I have no intention whatsoever of getting into the software business. Intel has no corporate competence in entertainment software. We don't know how to do video games, so forget it. We're not trying to go into their space. We're trying to get them on the same strategic road map so that the overall ecosystem will benefit.

Intel entered all 9 of the nine markets in which Intel managers reported to us that they believed that Intel had both the necessary technical and commercial capabilities, while of the 18 cases in which they believed Intel lacked at least one critical capability, the firm entered only 8.5 of the 8 occurred during the Internet bubble, and appear to have reflected the rather different strategic priorities of the firm during that period 9 .

However understanding Intel's actions in light of the existing literature - even with this promising beginning - is complicated by the fact that the complementary markets Intel faces are both more dynamic and more numerous than can be encompassed in a formal model. Most importantly, in the "90s the "ecosystem" was both highly dynamic and "multi-layered". Whereas the standard treatment of the problem considers the case of a monopolist in one market considering integrating into a second, Intel faced something

\footnotetext{
${ }^{8}$ Interview with Claude Leglise, director of the Developer Relations Group, Intel Corp., Santa Clara, November 13, 1997.

${ }^{9}$ A major strategic shift occurred between 1998 and 2001. For the first time in a decade, Intel's profits fell, and the firm was obliged to cut its dividend. Management lost faith in its microprocessor business' ability to grow the firm and meet stockholders' expectations. In 1997, Craig Barrett, then Chief Operating Officer of Intel, noted that "microprocessors by themselves will not be the growth engine that they have been in the past." Meanwhile, the opportunities offered by rapidly emerging Internet-related markets seemed extremely promising. Intel made several attempts to diversify, harnessing internal frustrations that the single-minded focus on Job 1 had prevented the development of other businesses (Burgelman, 2002). Under Barrett's direction, Intel shifted its focus to regenerate growth by entering new markets: Intel entered in 5 markets during this period, namely Web hosting and online services, toys, audio products, internet appliances, and wired and wireless handheld PC accessories, in none of which it had previously identified internal organizational capability. Intel exited all of them by the end of 2001.
} 
closer to a "stack" of markets whose nature and extent could not be identified ex ante. (Figure 1)

\section{FIGURE 1: A STACK OF COMPLEMENTARY MARKETS}

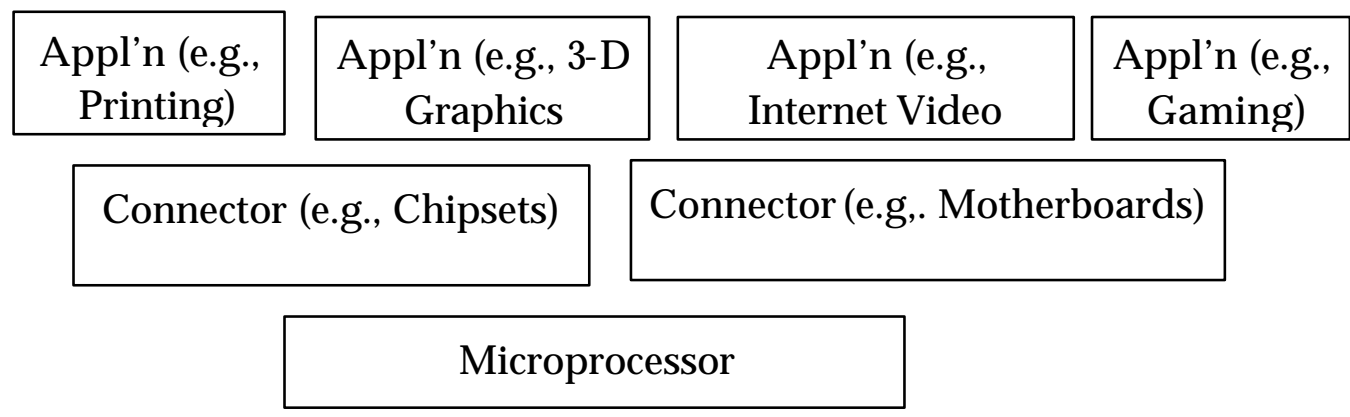

This stack was "dynamic" in the sense that technical progress and the evolution of demand continually expanded the potential set of "connector" and "application" markets, and in the sense that the nature of the interfaces between them was unknown ex ante.

All of these markets are "complements" in the classical sense, but some - notably the connector markets - are likely to be significantly more strategic than others. This is both because their existence enables other markets and thus because they have a disproportionate effect on demand, but also because in many cases they are central to the structure of competition. If Intel can retain architectural control over the interface markets - or at the very least prevent other firms from gaining control - it greatly increases the likelihood of Intel, in turn, retaining control of the microprocessor architecture.

Intel's entry decisions appear to have been shaped dramatically by whether a complementary market was viewed as a "connector" market or not. Of the 17 complementary markets that the firm entered, 12 entries were connector markets while the remaining 5 were the disastrous diversification attempts of the bubble years. These "interfaces" markets include chipsets, motherboards, and other network connectivity 
products. ${ }^{10} 11$ Of the 20 cases that we were told had significant implications for the interface with the microprocessor Intel only entered 12 times, or $60 \%$ - possibly because it lacked the necessary capabilities. Table 1 summarizes these numbers. (The Appendix gives a variety of data on the 27 projects that Intel explored during this time period.)

\section{TABLE 1:INTEL'S DECISION TO ENTER:}

\begin{tabular}{|l|l|l|l|}
\hline & \multicolumn{3}{l|}{ Did Intel have the necessary capabilities? } \\
& Yes & Partially & No \\
\hline Connector Market & 9 entry & $\begin{array}{l}3 \text { entry } \\
8 \text { no entry }\end{array}$ & \\
\hline $\begin{array}{l}\text { Not a connector } \\
\text { market }\end{array}$ & & 1 no entry & $\begin{array}{l}1 \text { no entry } \\
5 \text { entry (followed by rapid exit) }\end{array}$ \\
\hline
\end{tabular}

They give the impression that under "normal" conditions Intel enters only those complementary markets that have implications for control of the platform architecture and only those for which it believes it has the requisite capabilities. The qualitative evidence appears to be consistent with this hypothesis. Intel's first entry into "connector" markets was in 1994. Intel invented a new "bus architecture" - the Peripheral Component Interface -- that increased bus speed by a factor of five, and that provided fast links to other crucial components of the PC, such as hard disk and graphics. ${ }^{12}$ Intel first attempted to leave the production and commercialization of the PCI to the traditional chipset makers on whom

\footnotetext{
${ }^{10}$ Chipsets embody the physical and electrical "interfaces" to the platform's new external interfaces, therefore provide an essential function of data transfer into and out of the microprocessor. A motherboard is the main circuit board in a PC, containing the microprocessor, the memory, and other support chips Network connectivity products embody physical and electrical connections between different components of the PC system when integrated into a network of computers and peripheral devices such as printers.

${ }^{11}$ Examples following PCI (1993) include the Universal Serial Bus (USB) launched in 1997, followed by the Advanced/Accelerated Graphics Port (AGP) in 1997, and another bus dedicated to fast graphics (FireWire, also called IEEE 1394) in 1998, and the wireless data transfer protocol BlueTooth (1998). More recent interfaces include Universal Plug-and-Play, Wireless USB, and Ultra-Wideband (UWB) wireless radio technology in 2004 (USB transmits data between consumer electronics, PC peripherals and mobile devices within short range at very high speeds). Source: Intel Annual Reports 1996-2003 and Intel Press Release, February 18, 2004.

$12 \mathrm{Yu}$ (1998), p.55. A bus is a data pathway that ensures data transfer between different components of the PC.
} 
Intel had historically relied, but after being disappointed with their performance Intel ended up deciding to enter this market itself.

Entry was justified on both technical and strategic grounds. On the technical front Will Swope, vice president of the Intel Architecture Business Group, explained:

The real way you make money is by selling faster processors. And you can't sell a faster processor if you don't have data to operate on- [data that is brought to the chip through the chipsets. $]^{13}$

On the strategic front, Bill Miller, from the Sales and Marketing group, explained:

We got into the chipset business in a major way to accelerate platform transitions. To unleash the power of the Pentium, we had to introduce the new PCI bus.[..]. Our market segment share in the desktop chip set business is equal or greater than processors. This helps our ability to establish platform standards significantly. Having some market segment share in chip sets makes it easier for us to advance the platform.

Our foray into the motherboard business used to be sort of a manufacturing foray, and now is more of a licensing foray. We manufacture some, but mostly we have licensed our designs. This allows us to have influence over other areas of the platform as well. If you are defining how a certain percentage of the motherboards are designed, you then can make a good technical argument and have a good volume argument. Standards follow volume, which seems pretty obvious. The simplest way to get a standard established is to put in a product that sells at a high volume. ${ }^{14}$

By developing chipsets and selling them in large volume, Intel attempted to accelerate the adoption of a bus standard, which the firm saw as crucial both to growing the market for Intel microprocessors and to maintaining Intel's control over the architecture of the local system. Maintaining control also allowed Intel to ensure that the markets for complements that were running "on top of" the connectors was suitably competitive. In the words of Craig Kinnie, director of the Intel Architecture Lab for much of 1991-2000:

We want to define how these companies will hook their pipe to the PC and how application writers can take advantage of that pipe that we control [...]. They all will connect to the PC in exactly the same way.[...] Coordination here now creates a common connector. [...] Because we said

\footnotetext{
13 Interview with Will Swope, vice president, Intel Architecture Business Group and director, Platform Planning, Hillsboro, Oregon, August 6, 1998.

14 Interview with Bill Miller, August 13, 1998, then director of Worldwide Media Relations, Sales and Marketing Group, Intel Corp., SantaClara, California. Emphasis added.
} 
there should be one way to hook to a PC and we are going to make it happen, they all now have to compete to deliver to that socket, -- whereas if they had been all allowed to have a different connector and one of them won, there wouldn't even be competition: it would be one guy or two. ${ }^{15}$

This concern with stimulating demand and maintaining control was tempered, as the raw numbers suggest, by the recognition that Intel did not have the organizational capabilities required to enter all possible complementary markets. In chipsets, entry was justified on the basis of a good match between the requirements of the market and Intel's capabilities. Said Bill Miller from the Sales and Marketing Group:

We did start by giving specifications [to the chipset manufacturers]. [...] But we realized that they weren't fast enough, and one of the most troublesome things was that it was really hard getting the other chipset vendors to do PCI "right." It was so close to the processor that we wanted them to do it right, because our product ramp on Pentium was gated by the fact that you needed a PCI bus to do it. The [previous industry] bus [standards] were at the time were too stinking slow to show the benefit [of our platform]. We had to "put our own skin in the game." We got impatient and we said, "This is not fast enough." So, our PCI Components Division [...] entered the chipset business. We now provide chipsets, -- and, as we happen to execute really well in chipsets, we are now in the chipset business in a significant way: our market segment share in the desktop chipset business is equal or greater than in processors. ${ }^{16}$

This strategy, however, presents Intel with exactly the dilemma identified in the literature. Intel believed that it did not have the capabilities to identify all possible innovations in all possible complementary markets. But given that Intel had a history of entering complementary markets - and that this entry put it in a particularly advantageous position with respect to other potential markets - it faced the difficult task of committing to potential entrants that it would not act engage in precisely the kind of ex-post squeeze identified by the literature.

Our respondents appeared to have deeply internalized this issue. As Dave Johnson explained:

\footnotetext{
${ }^{15}$ Interview with Craig Kinnie, director of Intel Architecture Lab, Intel Corp., Hillsboro, Oregon, November 11, 1997.t.

16 Interview with Bill Miller, op. cit.Emphasis added.
} 
The market segment gets hurt if third parties think: "Intel, the big guys, are there, so I don't want to be there. They're going to crush me." That's not good, and it's not what we want, because we're trying to encourage people to do these complementary things! ${ }^{17}$

Similarly, in the context of the firm's experience with videoconferencing Dave Johnson, engineering manager at IAL, recalled:

You [as a platform owner] need to be careful not to come in so hard that you don't undermine the conditions in the market you enter. In some ways, what we did with ProShare ${ }^{18}$ was to enter the market segment with a product and expect the market to respond. But then you have to be careful because you can undermine the whole market segment and not end up fostering innovation. Some people claim we did just that. We wanted to deliver an affordable product that would make videoconferencing a desktop PC add-on. We were so intent on videoconferencing as a method for selling CPUs ${ }^{19}$ that our own products drove the prices down to where the channel [i.e., the existing players] wasn't making money, we weren't making money, competitors couldn't make money - and, therefore, we didn't help the overall marketplace. Major players are still there, but they are weak. A number of the more peripheral players have left.

Notice that the "layered" nature of the technical system in which Intel was embedded and the continuous evolution of the boundaries between components - made this problem particularly acute. Once Intel had entered an interface layer, for example, the problem of encouraging entry nto related markets did not disappear - rather it became significantly more acute since the interface was only likely to be valuable if there was entry into the markets that ran "on top" of it. As the platform continuously evolved, Les Vadasz, director of Intel Capital - the venture capital branch of Intel --, acknowledged that evolving platform boundaries created "skirmishes" with complementors:

In our business, the boundary has always moved because the interfaces between our customers and us have always changed as a result of the way the technology has evolved. While I recognize that it's moving and that it's always moved, it's very important that we don't get carried away with our own delusions of grandeur, and that we stay in businesses that we know we can succeed in... We have looked at our business more as a supplier of building blocks that others can build their business on, and that continues

\footnotetext{
17 Interview with David B. Johnson, director of the Media and Interconnect Technology Lab, Intel Architecture Lab, Intel Corp., Hillsboro, Oregon, August 4, 1998.

${ }^{18}$ ProShare was Intel's $\$ 750$ million failed videoconferencing effort (1992-1998).

${ }^{19} \mathrm{CPU}$ (Central Processing Unit) is another name for microprocessor.
} 
to be the majority of our business. But even there, we have skirmishes sometimes because the interface changes. When we first started to sell motherboards, there was a lot of paranoia amongst our OEMs. What's our intent? Why are we doing this? I think now it's more of a positive to the business than a negative. But anytime you do that, there are a lot of issues. Also, it's important that your complementors trust you because you need them, they need you, and you cannot just trample all over everybody's business willynilly. 20

Dr. Grove, CEO of Intel at the time of the interview summed this perspective up:

We are in a certain business and we are defining a platform upon which other people are going plug in peripherals or other products. And we want competition in those areas. And yet we want to supply there, also.

[Isn't there a tension there?] Yes, precisely: we are defining the platform and we want to be a participant to build on the platform. It's a pretty common situation. It is almost inconceivable that you can have the expertise, the momentum, and the market credibility to define a platform unless you are participating both above and below that platform. Microprocessors are below. You can't come and define buses if you don't know enough about chipsets and microprocessors. On the other hand, if you are in it, you obviously have a business interest for yourself. The resolution of these tensions is crucial for repeated success. You get to fool some of the people some of the time, but you can't make that an ongoing practice. $^{21}$

Intel's actions, and the dilemma that it faced, are broadly consistent with the existing literature. It is in the analysis of the actions that Intel took to resolve the dilemma that we begin to enter new ground.

Intel's first response was to attempt to develop a reputation for "treating complementors well" and to that end the company developed a rhetoric which presented Intel as a benevolent industry coordinator, or "honest broker", careful to protect incentives for external complementors. In the words of Claude Leglise:

You have to manage the future of the ecosystem. It's really a complete system with lots of people. So the role that we're trying to play is one of leadership -- which is very different from wanting to own everything. Our future wealth is completely tied to the wealth of the ecosystem and the

\footnotetext{
${ }^{20}$ Interview with Les Vadasz, senior vice president and director of the Corporate Business Development group (renamed Intel Capital in 2000), Intel Corporation, Santa Clara, California, August 14, 1998.

${ }^{21}$ Interview with Dr. Andrew S. Grove, CEO, Intel Corp., Santa Clara, August 18, 1998. Emphasis added.
} 
well being of the ecosystem. Therefore, it is to our advantage to make sure that this whole thing evolves positively. ${ }^{22}$

It may be that Intel did indeed develop a reputation for behaving this way - we did not have the opportunity to interview any actual or potential complementors and are thus unable to gauge whether this was a successful strategy. Here we focus on the degree to which Intel used its organizational structure and processes to commit to complementors that it would not engage in exactly the kinds of "ex-post squeezes" identified in the literature. Intel's approach to this issue is complex, and we believe that it highlights a number of important issues. The key to understanding Intel's actions, we believe, is, first, to unpack the concept of "ex-post squeeze" and second, to understand that ways in which Intel attempted to use organizational structure and practices as a commitment mechanism.

In principle there are two ways in which Intel can "squeeze" complementors. It can drive returns in a complementary market to zero by entering the market and depressing prices - effectively subsidizing entry using profits derived from the primary component or it can enter and capture all the returns for itself by manipulating the boundary between the market and the core of the platform in order to advantage Intel owned products. Intel can thus either attempt to commit never to enter complementary markets - a difficult task given its history and its obvious economic incentives - or it can commit to enter and "play nicely" - by making money but not too much. In our view it is this second strategy that Intel pursued, and they did so by attempting to leverage both their intellectual property strategy and their internal organizational structure and processes.

Intel committed to making money in those complementary markets that it did enter - and thus not to drive returns down in those markets - by committing to "job 2" by organizing entry into such markets as organizationally distinct units that were measured and rewarded on the basis of their own profit and loss. It then committed not to making too much money in these markets by aggressively subsidizing entry into these markets, and by sharing the Intel owned IP that might otherwise give the Intel owned firm undue advantage. This balancing act created very significant tensions within the firm th at were managed by institutionalizing the strategic imperative to stimulate entry in the

\footnotetext{
22 Interview with Claude Leglise, op. cit .
} 
market for complements while simultaneously entering those markets and making money - but not too much - by stressing that the task of expanding demand for the microprocessor (a task referred to as "Job 1" within Intel) might at times be in contradiction to the task of growing profitable businesses based on proprietary IP in complementary markets ("Job 2"), and by structuring the organizational unit responsible for the development of the majority of the IP - the Intel Architectural Labs, or IAL, as a stand alone, not for profit unit.

Mike Aymar, vice president and general manager, Desktop Products Group, discussed how this tension affected the treatment of Intellectual Property in the context of Digital Video Disk (DVD) technology:

We worked with the suppliers and came up with some software technology for doing the [DVD] copyright encryption. We also worked with some participants to come up with an MPEG2 player that works on a PC, with no additional hardware - so once you buy a certain level of PC, this is "free." Now, what do we do with that technology? If it is Job 1, we probably broadly diffuse it. We make it available to as many participants as we can, so that as many PCs in the world from any supplier, any hardware supplier, any software supplier, all have this capability. And we just broadly diffuse it. We may license some things, we may charge small royalties, but in general, our main purpose is to enable and diffuse this technology broadly.

If it is not Job 1, if it is its own business unit, they don't want to diffuse it broadly. They want to take that cool software we developed and go sell it one-on-one to Compaq, Hewlett-Packard, and NEC in Japan. And they want to do that in competition with the other people who might be selling similar software. They don't want to enable the other people. They want to go win the business on their own. They want to charge money for it. They want to make a profit. So, you have two very different ways of acting. ${ }^{23}$

Notice that Mike Aymar's comment highlights the fact that the units created to exploit complementary markets are explicitly designed to encourage their managers seek profits, but that at the same time the firm creates an expectation that the unit may need to compete “on level ground".

\footnotetext{
${ }^{23}$ Interview with Mike Aymar, vice president and general manager, Desktop Products Group, Intel Corporation, Santa Clara, California, November 13, 1997.
} 
Jim Pappas, the director of Platform Initiatives at IAL also commented on the ways in which this policy created tensions Intel's chipset business group and IAL.

We developed the [USB] code and we gave it to our internal chipset business group in Chandler, Arizona, who used it to do their chip. And we also made it available to anybody in the industry. I can guarantee that there were times where the group in Chandler was livid with me for freely distributing this. They have competitors out there who are building products. $^{24}$

Thus one key element of the strategy was the creation of independent units charged to do nothing but execute on "job 2" - who were "livid" when other elements of the organization (in this case IAL) took actions that would plausible reduce their profitability.

The second element, however, was the active subsidization of entry into complementary markets. Intel subsidized entry extensively, but, intriguingly, believed that direct financial subsidies to complementors were found to be counterproductive. Claude Leglise explained that he had a policy of refusing to fully subsidize entry -insisting that complementors' "put their skin in the game."

The one thing that I have consistently refused to do (although we may have done it once or twice by accident) is to pay people [external complementors] to do a job. Tell them "I want this kind of software, build it". I don't want to do that because again, back to my premise, we don't know software, they do. I'm much more interested in saying "this project is very exciting. Our strategy and your strategy are very consistent, we both agree it's risky: I will help you mitigate the risk, I'll pay half of it. But you pay the other half. I want you to have some skin in it. So you are interested in making it successful." I want them to be successful, on their own with their business model.

...If you look at history... rumor has it that IBM spent a billion dollars on applications for OS2 but they bought people, they said "here, do this for $\mathrm{me}^{\prime}$. And at the end, the companies turned around and said "here, it's done" - and IBM said "well, aren't you going to sell it, market it? They said "well no, our deal is to develop it: you've got it, now good luck." The same with Philips and the CD-Rom Interactive (technology): Philips did $\mathrm{CDI}$ and they sprinkled money over the entire industry. It did terribly. And they had all these developers developing stuff but there was no business model - the business model was "I'll pay you". 25

\footnotetext{
${ }^{24}$ Interview with Jim Pappas, director of Platform Initiatives, Desktop Products Group, Intel Corporation., Hillsboro, Oregon, August 4, 1998. Emphasis added.

${ }^{25}$ Interview with Claude Leglise, op. cit.
} 
Instead Intel used an impressively wide variety of subsidies, including the facilitation of innovation through early diffusion of Intel technology and IP (we return to this point below and to its implications for Intel's ability to commit not to squeeze entrants ex post), the sharing of engineers, the facilitation of access to market through sharing of marketing and commercialization resources, industry coordination initiatives including compliance forums and Developers Forums and the sharing of development tools such as Software Development Kits.

For example, the Intel Developer Relations Group's resources ${ }^{26}$ were devoted to help external software developers innovate on software that was specifically designed to be complementary to Intel's latest microprocessors. It provided a range of assistance, including grants to external software developers, sharing market information, facilitating entry into new markets, and sharing with them Intel technology before it appears on the market - which them an edge over their competitors. As Leglise explains:

The first thing we'll tell [external software developers] is to share with them our strategy. "Here is our best understanding of what's going to happen. We are sharing with you our plan, our best view of the market, and you have the opportunity to plan. [...] For example, last year, my organization took something like 20 software companies to China. We organized meetings with the government, the retailers, the hardware and software distributors, and we introduced them to the minister of technology, the minister of telecommunications, 20 different retailers, 30 different computer companies, and in the matter of a month they were up and running. Now, every one of them has at least on deal cooking, where they're exporting their software into China.

The second thing I do I give them early access to technology, i.e., to our latest generation of microprocessors six to 12 months before the market, which means six to 12 months before their competitors. [...] We give them tools to get started. Just on the hardware side it's a five to seven million dollar effort. ${ }^{27}$

The Software Developer Relations group also allied with Intel Marketing and Sales group to facilitate external software developers' commercialization of their software.

\footnotetext{
26 The Intel Develop Relations Group counted approximately 200 persons in 1998.

27 Interview with Claude Leglise, op. cit .
} 
Sometimes, Intel took charge of selling the software directly to Original Equipment Manufacturers $(\mathrm{OEMs})^{28}$, and paid the external complementors as royalties.

We also help them with sales and marketing. We have done a decent job on selling the software that is bundled with computer systems by the OEMs. We sell it to the OEMs, [with whom we have privileged relationships], and the software companies get a royalty. ${ }^{29}$

Table 2 summarizes the extent to which Intel licensed the IP associated with the complementary markets that it explored:

TABLE 2:INTEL'S DECISION TO SHARE IP:

\begin{tabular}{|l|l|l|l|}
\hline \multirow{2}{*}{} & \multicolumn{3}{|l|}{ Did Intel have the necessary capabilities? } \\
\cline { 2 - 4 } & Yes & Partially & No \\
\hline Connector Market & 9 entry & $\begin{array}{l}\text { 3 entry } \\
\text { 2 IP share, 1 not } \\
8 \text { no entry } \\
7 \text { IP share, 1 not }\end{array}$ & \\
\hline $\begin{array}{l}\text { Not a Connector } \\
\text { Market }\end{array}$ & 9 share IP & $\begin{array}{l}\text { 1 no entry } \\
\text { No IP share }\end{array}$ & $\begin{array}{l}\text { Sho entry } \\
\text { Share IP } \\
\text { Nontry (followed by rapid exit) } \\
\text { No IP share }\end{array}$ \\
\hline
\end{tabular}

At one level these subsidies can be viewed as analytically equivalent to direct entry by Intel itself, and our reading of the literature is that this has been the tacit assumption of many who have studied this issue. But our experience at Intel leads us to believe that this may be a misleading simplification. Subsidies - particularly those that reduce the costs of all potential entrants and that simultaneously make it harder for Intel to engage in any $e x$ - post squeeze - and our interpretation of the widespread dissemination of IP is that it has exactly this characteristic - appear to be a particularly elegant way to solve Intel's dilemma. They encourage the entry of a wide range of firms with a wide range of skills, thus plausibly driving demand for the microprocessor. And they also make it quite difficult for Intel to make "too much"

28 PC makers such as Compaq, IBM, Gateway, Dell are OEMs.

${ }^{29}$ Interview with Claude Leglise, op. cit. 
money in those markets that it does choose to enter - hence Jim's description of his colleague as "livid".

Of course a reduction in entry costs is only likely to be effective in inducing entry if potential entrants believe that Intel is not likely to change its mind and that, for example, the next release of IP is likely to be as open, as widely disseminated, as the current one, and that Intel will not use it's unique knowledge of the system architecture to advantage its own participants.

Intel appears to be very aware of this danger, and to have structured the IAL the Intel Architectural Lab - as a not for profit unit for precisely this reason. Andy Grove was quite explicit in his belief that the structuring of IAL as a not for profit unit significantly increased Intel's credibility in the market place:

Wherever possible, it is much better that the standards be done by a group that is not a Profit-and-Loss center. That's where IAL came in. IAL, by and large, was created as an architecture lab, as its name implies. IAL has no profit and loss responsibility, and no products. Most of this work was done by IAL. And IAL has achieved an extra measure of credibility. It comes, first, from the fact that they are very good, and second, that they are not in a business. For the CEG organization ${ }^{30}$ to proselytize platform design and architecture was much more difficult than for IAL, because CEG would be a supplier to that platform. ${ }^{31}$

Jim Pappas's extended remarks convey his apparent internalization of this imperative:

We developed the [USB] code and we gave it to our internal chipset business group in Chandler, Arizona, who used it to do their chip. And we also made it available to anybody in the industry. I can guarantee that there were times where the group in Chandler was livid with me for freely distributing this. They have competitors out there who are building products. So, there came a point where they were out there trying to sell their chips and they would go into an account and they would explain why they should buy the Intel chips. And the people would say, "Well, I'm trying to decide between you and this other guy, and this other guy uses the same [technology] as you do."

They would tell us at IAL, "Jim, you have to stop distributing this thing because I want to sell my product and you're basically adding credibility to these other people because they're using the same Intel circuits that we are

\footnotetext{
30 CEG was the Computer Enhancement Group, which was the business group that made and sold chipsets and motherboards.

${ }^{31}$ Interview with Dr. Andrew S. Grove, op. cit. Emphasis added.
} 
using. And so we want you to stop that." I said, "No, we're not going to stop that." This is yet another example of knowing what your primary objective is. 32

Many of the managers to whom we spoke at IAL were quite explicit about their view of themselves as enablers of entrant success. Dave Ryan, director of Technology Marketing at IAL, made it clear that IAL was assigned solely to make basic technological components (as opposed to finished products) and to "enable" innovation in the industry:

We don't make products at IAL. We make product components. The core-the conferencing standards, the engines for processing the standards-based data streams, and the engines to encode and decode video and audio-all those basic components were developed by IAL. They're pieces, component parts of a product. ${ }^{33}$

Similarly Carol Barrett, an IAL marketing manager in multimedia software, saw her job at IAL as helping sell more Intel microprocessors, by partnering, not competing, with external developers of multimedia solutions:

I definitely don't want to compete with 3D editing companies. My job is demand-creation, so $I^{\prime} m$ trying to help sell our nextgeneration microprocessors. I'm not trying to sell 3-D engines. My basic mechanism for diffusion is all about partnering to provide solutions to the market. We build media components. We don't build products that are full solutions, but components that really need to be incorporated into full 3D editing and creation products, for which there are market segment leaders out there that are well established and have excellent products. [...]. We produce a component that could be included in their product ${ }^{34}$

Herman D'Hooge, manager in the IAL Media Interconnect Technology group, described IAL's "neutrality":

IAL has this neutrality [...]. Neutrality means that we really try to do this to the betterment of the whole PC industry and not just to the betterment of Intel. [...] We are just doing this for the goodness of the whole industry but we are privy to a lot of inside information that these people [external firms] have and we must be careful not to broker that information to potential Intel product groups that might be able to use it. They [external

\footnotetext{
32 Interview with Jim Pappas, director of Platform Initiatives, Desktop Products Group, Intel Corporation., Hillsboro, Oregon, August 4, 1998. Emphasis added.

33 Interview with Dave Ryan, director of Technology Marketing, Intel Architecture Lab, Intel Corp., Hillsboro, Oregon, August 4, 1998.

${ }_{34}$ Interview with Carol Barrett, Marketing Manager, Intel Architecture Lab, Intel Corp., Hillsboro, Oregon, August 5, 1998.
} 
firm] are willing to open up and tell you their secrets about their road map, what they see happening, and where they want to go with PCs, -- but they don't want to make the information readily available to a competing product group in Intel. So, we receive information that we will not share with product groups within Intel, simply because it would be a breach of our neutrality in the industry. It is in our best interest for the Lab neutrality not to go straight over to here and say, 'Oh, guess what they just told me, under non-disclosure.' ${ }^{35}$

Jim Pappas summarized the overall strategy beautifully - Intel attempts to "show faith in the future" (by competing in, and attempting to profit from, a complementary market) while simultaneously attempting to persuade potential entrants that Intel's operations wouldn't have access to preferential information. Intel will make money in this market, signaling that there is money to be made, while not making too much:

Once we decided we were going to put this in our chip set products, all of a sudden there were many people working on the design. But we had a very clear separation. We had a group that was defining the specification, and we had other groups implementing products. They would take our specification and implement the products, but we kept a sort of wall between the two.

For USB to be successful, it needs to be available to the industry, and the industry needs to believe and understand that they have a good shot at going off and implementing it and being successful with it. The best way to do that is to do it for real, and just to say that this group over here is defining the - and this group over there will get the specification. They're going to design a product - and we make it very clear that Intel is going to design products for this. We plan to sell a lot of products for these things. By doing so, we are showing faith in the future. So, even though we would develop products, at the same time, we would lose our credibility if we were saying that this is something we're only going to do for our internal products and we're not going to enable any competition here.

Other firms that would compete with the Intel product might worry that we would be giving preferential information to our product group. So, we took great pains not to do that. Our product group was running fast and hard with this technology, and that's good. ${ }^{36}$

\footnotetext{
${ }^{35}$ Interview with Herman D'Hooge, Manager, Media Interconnect Technologies, Intel Architecture Lab, Intel Corp., Santa Clara, California, November 12, 1997. Emphasis added.

${ }^{36}$ Interview with Jim Pappas, op. cit. Emphasis added.
} 


\section{CONCLUSION}

Our examination of Intel's history with respect to complementary markets and to potential complementors confirms the usefulness of much of the existing literature while highlighting a number of areas in which it could be usefully extended.

We find that Intel does indeed experience strong incentives to enter and/or subsidize the market for complements to its core asset - the microprocessor. Both entry and subsidy, however, are strongly conditioned by the firm's belief that because it cannot match the variety of competencies of potential entrants, sustaining a credible commitment not to engage in the ex-post squeeze of entrants is critical to its success.

Sustaining such a commitment is greatly complicated by the fact that when the interfaces between complementary markets are evolving rapidly Intel has particularly strong incentives to enter - and that such entry itself puts the firm in a particularly strong position to control the evolution of complementary markets because it gives the firm control over the IP that defines each market.

Intel's solution to this dilemma highlights a tension that to our knowledge has not been noted before. On the one hand Intel commits to making money in complementary markets - signaling that it will not drive returns down - by structuring entry into complementary markets as separate organizational units with Profit \& Loss responsibility ("Job 2"). But at the same time it commits that it will not make "too much" money in these markets by actively giving away IP and subsidizing competitive entry. This "commitment" is sustained both by formal and informal statements of the firm and by maintaining the organizational unit responsible for the development of key IP as an independent cost center whose mission is to extend the size and power of the entire "ecosystem" ("Job 1").

These results have implications for both the literature focused on the evolution and adoption of standards and for the literature that has explored the relationship between organizational structure and competition. With reference to the literature on complements and standards evolution, Intel's history underlines the complexity of the task of managing the evolution of an evolving architecture and the difficulty of making unambiguous welfare predictions in such cases. While it seems possible to conclude provisionally from the Intel case that foreclosing entry by third parties to the system almost certainly reduces 
consumer welfare, it also suggests that some entry by monopolists is almost certainly beneficial. More broadly, Intel's history suggests the utility of further work that is explicitly dynamic and multilevel, and that incorporates a heterogeneous distribution of capabilities as a fundamental assumption.

Within the organizational context, our results belong to the small stream of literature suggesting that organizational structure can have real competitive consequences. Given that a growing body of work in organizational economics suggests that organizational structure and practice may be difficult to change, understanding how organizational mechanisms may enable firms to commit to actions in the market place may be a particularly fruitfularea for further exploration. 


\section{REFERENCES}

Becchetti, L. and L. Paganetto, 2001, “The Determinants of Suboptimal Technological

Development in the System Company-Component Producers Relationship", International Journal of Industrial Organization, 19(9), 1407-1421.

Brandenburger, A. and B. Nalebuff, 1997, Co-opetition: A Revolutionary Mindset that Combines Competition and Cooperation, New York: Currency Doubleday.

Bresnahan, T.F. and S. Greenstein, 1999, "Technological Competition and the Structure of the Computer Industry", Journal of Industrial Economics, 47(1), 1-40.

Burgelman, R.A., 2002, Strategy is Destiny: How Strategy-Making Shapes a Company's Future, New York, NY: The Free Press, a Division of Simon and Schuster.

Caillaud, B. and B. Jullien, 2003, “Chicken and Egg: Competition among Intermediation Service Providers", RAND Journal of Economics, 34(2), 309-328.

Carlton, D.W. and M. Waldman, 2002, "The Strategic Use of tying to Preserve and Create Market Power in Evolving Industries", RAND Journal of Economics, 33(2), 194-220.

Choi, J.P. and C. Stefanadis, 2001, “Tying Investment and the Dynamic Leverage Theory", RAND Journal of Economics, 32(1), 52-71.

Cournot, A.A., 1838, Researches into the Mathematical Principles of the Theory of Wealth, N.T. Bacon trans., Macmillan 1897. A.M. Kelley, New York, 1871. Reprint of the 1927 edition.

Davis S.J., J. MacCrisken, and K.M. Murphy, 2002, "Economic Perspectives on Software Design: PC Operating Systems and Platforms", in Microsoft, Antitrust and the New Economy: Selected Essays, ed. Evans, D.S., 361-419. Springer. Previous version available for download at http://gsbwww.uchicago.edu/fac/steven.davis/research/

Farrell J., Monroe, H.K., and G. Saloner, 1998, “The Vertical Organization of Industry: Systems Competition versus Component Competition", Journal of Economics and Management Strategy, Fall, 7(2), 143-182.

Farrell J and M.L. Katz, 2000, "Innovation, Rent Extraction, and Integration in Systems Markets", Journal of Industrial Economics , December, 97(4), 413-432. 
Gawer, A., 2000, The Organization of Platform Leadership: An Empirical Investigation of Intel's Management Processes Aimed at Fostering Complementary Innovation by Third Parties, MIT PhD Thesis.

Hagiu, A., 2004, "Optimal Pricing and Commitment in Two-Sided Markets", Mimeo, presented at "The Economics of Two-Sided Markets" conference held in January 2004 at the University of Toulouse.

Hagiu, A., 2005, "Two-Sided Platforms: Pricing and Social Efficiency", Mimeo, Research Institute of Economy Trade and Industry and Princeton University. http://www.princeton.edu/\%7Eahagiu/job\%20market\%20paper\%204\%202.pdf

Heeb, R., 2003, "Innovation and Vertical Integration in Complementary Markets", Journal of Economics and Management Strategy, 12(3), Fall, 387-417.

Jackson, T., 1997, Inside Intel: How Andy Grove Built the World's Most Successful Chip Company, New York, NY: The Free Press.

Miller, D. A., 2005, "Invention Under Uncertainty and the Threat of Ex-Post Entry", February 25, Mimeo. Available at http://ssrn.com/abstract $=319180$

Nalebuff, B., 2004, "Bundling as an Entry Barrier", Quarterly Journal of Economics, February, 119(1), 159-187.

Ordover, J., A. Sykes, and R. Willig, 1985, “Nonprice Anticompetitive Behavior by Dominant Firms towards the Producers of Complementary Products", in Antitrust and Regulation Essays in Memory of John J. McGowan, Fisher, F., ed., Cambridge, MA: MIT Press.

Panzar, J.C., 1989, "Technological Determinants of Firms and Industry Structure", in Handbook of Industrial Organization, Schmalensee, R. and R.D. Willig, eds.,13.

Rochet, J.-C. and J. Tirole, 2003, "Platform Competition in Two-Sided Markets", Journal of the European Economic Association, 1(4), 990-1029.

- and J. Tirole, 2004, "Two-Sided Markets: An Overview", Mimeo, IDEI, University of Toulouse, presented at "The Economics of Two-Sided Markets" conference held in January 2004 at the University of Toulouse.

Schmalensee, R., 1981, “Monopolistic Two-Part Pricing Arrangements”, Bell Journal of Economics, 11, 445. 
Whinston, M.D., 1990, “Tying, Foreclosure, and Exclusion”, American Economic Review, September, 837-859.

West, J. and J Dedrick, 2000, "Innovation and Control in Standards Architectures: The Rise and Fall of Japan's PC-98", Information Systems Research, 11(2), June 2000, 197-216.

-------, 2003, “How Open is Open Enough? Melding Proprietary and Open Source Platform Strategies", Research Policy, 32(2003), 1259-1285.

\section{APPENDIX}

Appendix Table I. List of Intel Projects Analyzed

\begin{tabular}{|c|l|}
\hline & \multicolumn{1}{|c|}{ Proiect Name } \\
\hline 1 & Initiative: Networked Multimedia \\
\hline 2 & Initiative: Manageability \\
\hline 3 & Initiative: Big Pipes (also called Broadband) \\
\hline 4 & Initiative: Security \\
\hline 5 & Initiative: Anywhere -in-the-Home \\
\hline 6 & Initiative: Advance-the-Platform \\
\hline & \\
\hline 7 & Interface technology: PCI (Peripheral Component Interface) \\
\hline 8 & Interface technology: AGP (Advanced Graphics Port) \\
\hline 9 & Interface technology: USB (Universal Serial Bus) \\
\hline 10 & Interface technology: 1394 (also called FireWire) \\
\hline 11 & Interface technology: TAPI (Telephony Application Programming Interface) \\
\hline 12 & Interface technology: H.323 (interface for computer telephony) \\
\hline 13 & Interface technology: Home RF (Home Radio-Frequency) \\
\hline 14 & Interface technology: DVD (Digital Video Disk) \\
\hline 15 & Interface technology: CDSA (Security) \\
\hline 16 & Interface technology: Indeo (Intel Video Technology) \\
\hline & \\
\hline 17 & Products: Intel ProShare (Videoconferencing) \\
\hline 18 & Products: Hood River (PC in the family room) \\
\hline 19 & Products: Networking \\
\hline 20 & Products: Chipsets (for PCI, USB, AGP, etc.) \\
\hline 21 & Products: Motherboards (for PCI, USB, AGP, etc.) \\
\hline 22 & Products: Software \\
\hline & \\
\hline 23 & Consumer Services: Web Hosting and Online services \\
\hline 24 & Consumer products: Toys \\
\hline 25 & Consumer products: Audio products \\
\hline 26 & Consumer products: Internet Appliances \\
\hline 27 & Consumer products: Wired and Wireless Handheld products \\
\hline
\end{tabular}


APPENDIX TABLE II. INTEL'S ENTRY IN NEW MARKETS 1990-2004

\begin{tabular}{|c|c|}
\hline Product & Year of Entry /Year of Exit (when applicable) \\
\hline Chipsets & $\begin{array}{l}\text { - Date of entry: } 1991 \\
\text { - Seen as mostly a complementary market to PC } \\
\text { microprocessors - profits not seen as the priority, rather, to } \\
\text { facilitate the industry transition to next versions of Intel } \\
\text { processors, } \\
\text { - Competencies required: close to existing competencies } \\
\text { - Date of exit: no exit. Still thriving as of } 2005\end{array}$ \\
\hline Motherboards & $\begin{array}{l}\text { - } \quad \text { Date of entry: } 1995 \\
\text { microprocessors - profits not seen as the priority -- rather, } \\
\text { to facilitate the industry adoption to next versions of Intel } \\
\text { processors } \\
\text { - Competencies required: close to existing competencies } \\
\text { Date of exit: no exit. Still thriving as of } 2005\end{array}$ \\
\hline $\begin{array}{l}\text { Videoconferencing (with ProShare software) } \\
\text { - digital PC cameras which could also be used for video } \\
\text { phone calls, enhancement cards that co ntained a digital } \\
\text { modem and audio/video compression/decompression } \\
\text { (CODEC) circuitry. }\end{array}$ & $\begin{array}{l}\text { - } \quad \text { Date of entry: } 1994 \\
\text { - Seen as a market in which big profits were expected, as } \\
\text { - } \quad \text { Nell as a complementary market to microprocessors } \\
\text { - } \quad \text { Date of exit: } 1999\end{array}$ \\
\hline $\begin{array}{l}\text { Networking (Network Connectivity) } \\
\text { - Network adapters } \\
\text { - "AnyPoint" networking solutions to share IT access, } \\
\text { music, printers, etc. } \\
\text { - Bluebooth products, to create wireless connections } \\
\text { around the mobile computer with mobile phones, } \\
\text { Personal Digital Assistants, etc. }\end{array}$ & 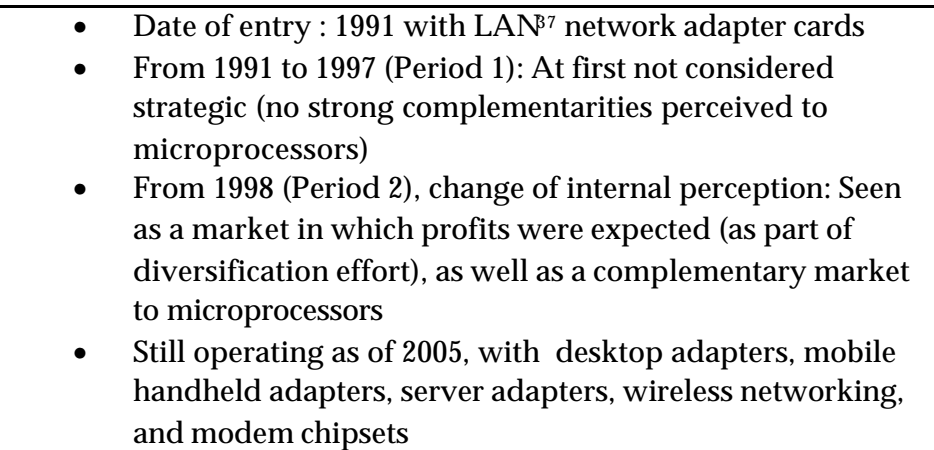 \\
\hline Web Hosting, Intel Online Services & $\begin{array}{l}\text { - } \quad \text { Date of entry: } 1999 \\
\text { - } \quad \text { neen mostly as a new arena to diversify in and compete, } \\
\text { - } \quad \text { Third party innovation: not critical } \\
\text { - } \quad \text { New competency required } \\
\text { - } \quad \text { Date of exit: June } 2002\end{array}$ \\
\hline $\begin{array}{l}\text { PC Toys, Intel Play products } \\
\text { - QX3 Plus computer microscope } \\
\text { - Sound Morpher, Me2Cam virtual game system }\end{array}$ & $\begin{array}{ll}- & \text { Date of entry: } 1999 \\
- & \text { Date of exit: } 2001\end{array}$ \\
\hline $\begin{array}{l}\text { Consumer Audio products } \\
\text { - personal audio player } \\
\text { - music system software }\end{array}$ & $\begin{array}{ll}\text { - } & \text { Date of entry: Jan } 2001 \\
\text { - } & \text { Intel's \$299 digital music player, launched Feb } 01 \\
\text { - } & \text { Date of exit: Connected Products Division shut in Oct } 01\end{array}$ \\
\hline $\begin{array}{l}\text { Consumer Internet (wireless and handheld) Appliances } \\
\text { - ChatPad } \\
\text { - WebPad }\end{array}$ & $\begin{array}{ll} & \text { Date of entry: Jan } 2001 \\
\text { - } & \text { Date of exit: late } 2001\end{array}$ \\
\hline $\begin{array}{l}\text { Consumer Wired and Wireless PC Accessories } \\
\text { - wired series: keyboard, mouse } \\
\text { - wireless series: keyboard, mouse and game-pad }\end{array}$ & $\begin{array}{l}\quad \text { Date of entry: June } 2000 \\
\text { - } \quad \text { Date of exit: late } 2001\end{array}$ \\
\hline
\end{tabular}

${ }^{37}$ LAN $=$ Local Area Network. A computer network that spans a relatively small area 
APPENDIX TABLE III. DRIVERS OF INTEL'S ENTRY IN COMPLEMENTARY M ARKETS 1990-2004 (1 / 3)

\begin{tabular}{|c|c|c|c|c|c|c|c|c|c|}
\hline & Projects & $\begin{array}{l}\text { Type of } \\
\text { Project }\end{array}$ & $\begin{array}{l}\text { Did Intel } \\
\text { believe that } \\
\text { this project will } \\
\text { help Job 1? - ie } \\
\text { was it a } \\
\text { complementary } \\
\text { market? }\end{array}$ & $\begin{array}{l}\text { Were the } \\
\text { corresponding } \\
\text { market products } \\
\text { physically } \\
\text { embodying one or } \\
\text { several interfaces - } \\
\text { i.e., was this a } \\
\text { "connector" market? }\end{array}$ & $\begin{array}{l}\text { Did Intel } \\
\text { enter the } \\
\text { market? }\end{array}$ & $\begin{array}{l}\text { Did Intel } \\
\text { exit } \\
\text { later? }\end{array}$ & $\begin{array}{l}\text { Did Intel have } \\
\text { the } \\
\text { technological } \\
\text { and commercial } \\
\text { capabilities to } \\
\text { succeed in this } \\
\text { markets? }\end{array}$ & $\begin{array}{l}\text { Did Intel } \\
\text { share } \\
\text { Intellectual } \\
\text { Property for } \\
\text { low royalties? }\end{array}$ & $\begin{array}{l}\text { Did Intel } \\
\text { engage in cross- } \\
\text { industry } \\
\text { coordination, or } \\
\text { in other forms } \\
\text { of facilitation of } \\
\text { complementors' } \\
\text { innovation? }\end{array}$ \\
\hline 1 & Networked Multimedia & Initiative & $\overline{\mathrm{Y}}$ & $\mathrm{Y}$ & $\mathrm{Y}^{38}$ & $\bar{Y}$ & YN & $\mathrm{N} / \mathrm{B}^{39}$ & $\mathrm{Y}$ \\
\hline 2 & Manageability & Initiative & $\mathrm{Y}$ & $\mathrm{Y}$ & $\mathrm{Y}^{40}$ & $\mathrm{~N}$ & $\mathrm{Y} / \mathrm{Y}$ & $\mathrm{Y}$ & $\mathrm{Y}$ \\
\hline 3 & Big Pipes (Broadband) & Initiative & $\bar{Y}$ & $\bar{Y}$ & $\mathrm{Y}^{41}$ & $\bar{Y}$ & YN & $\overline{\mathrm{Y}}$ & $\overline{\mathrm{Y}}$ \\
\hline 4 & Security & Initiative & $\bar{Y}$ & $\bar{Y}$ & $\overline{\mathrm{N}}$ & $\mathrm{N} / \mathrm{A}$ & $\mathrm{YN}$ & $\bar{Y}$ & $\bar{Y}$ \\
\hline 5 & Anywhere-in-the-Home & Initiative & $\mathrm{Y}$ & $\mathrm{Y}$ & $\mathrm{N}$ & $\mathrm{N} / \mathrm{A}$ & YN & $\mathrm{Y}$ & $\mathrm{Y}$ \\
\hline 6 & Advance-the-Platform & Initiative & $\mathrm{Y}$ & $\mathrm{Y}$ & $\mathrm{Y}^{42}$ & $\mathrm{~N}$ & $\mathrm{Y} / \mathrm{Y}$ & $\bar{Y}$ & $\bar{Y}$ \\
\hline 7 & $\begin{array}{l}\text { PCI (Peripheral Component } \\
\text { Interface) }\end{array}$ & Interface & $\bar{Y}$ & $\bar{Y}$ & $\bar{Y}$ & $\mathrm{~N}$ & $\mathrm{Y} / \mathrm{Y}$ & $\bar{Y}$ & $\mathrm{Y} / \mathrm{N}^{43}$ \\
\hline 8 & $\begin{array}{l}\text { AGP (Advanced Graphics } \\
\text { Port) }\end{array}$ & Interface & $\bar{Y}$ & $\bar{Y}$ & $\bar{Y}$ & $\bar{N}$ & $\mathrm{Y} / \mathrm{Y}$ & $\bar{Y}$ & $\mathrm{Y} / \mathbb{N}^{43}$ \\
\hline 9 & USB (Universal Serial Bus) & Interface & $\bar{Y}$ & $\bar{Y}$ & $\mathrm{Y}$ & $\mathrm{N}$ & $\mathrm{Y} / \mathrm{Y}$ & $\bar{Y}$ & $\mathrm{Y} / \mathrm{N} 43$ \\
\hline 10 & 1394 (also called FireWire) & Interface & $\bar{Y}$ & $\mathrm{Y}$ & $\mathrm{Y}$ & $\mathrm{N}$ & $\mathrm{Y} / \mathrm{Y}$ & $\bar{Y}$ & $\bar{Y} / \mathbb{N}^{43}$ \\
\hline 11 & $\begin{array}{l}\text { TAPI (Telephony Application } \\
\text { Programming Interface) }\end{array}$ & Interface & $\mathrm{Y}$ & $\mathrm{Y}$ & $\mathrm{N}$ & $\mathrm{N} / \mathrm{A}$ & YN & $\mathrm{Y}$ & $\mathrm{Y}^{43}$ \\
\hline 12 & $\begin{array}{l}\text { H.323 (interface for computer } \\
\text { telephony) }\end{array}$ & Interface & $\bar{Y}$ & $\bar{Y}$ & $\mathrm{~N}$ & $\mathrm{~N} / \mathrm{A}$ & $\mathrm{YN}$ & $\bar{Y}$ & $\mathrm{~N} / \mathrm{A}^{43}$ \\
\hline 13 & Home Radio-Frequency & Interface & $\mathrm{Y}$ & $\mathrm{Y}$ & $\mathrm{N}$ & N/A & YN & $\mathrm{Y}$ & $\mathrm{Y}$ \\
\hline 14 & DVD (Digital Video Disk) & Interface & $\bar{Y}$ & $\bar{Y}$ & $\mathrm{~N}$ & $\mathrm{~N} / \mathrm{A}$ & YN & $\bar{Y}$ & $\bar{Y}$ \\
\hline 15 & CDSA (Security) & Interface & $\bar{Y}$ & $\bar{Y}$ & $\mathrm{~N}$ & $\mathrm{~N} / \mathrm{A}$ & YN & $\bar{Y}$ & $\bar{Y}$ \\
\hline 16 & Indeo (Intel Video) & Interface & $\mathrm{Y}$ & $\bar{Y}$ & $\mathrm{~N}$ & $\mathrm{~N} / \mathrm{A}$ & YN & $\mathrm{N} / /^{44}$ & $\mathrm{~N} / \mathrm{A}^{43}$ \\
\hline 17 & $\begin{array}{l}\text { Intel ProShare } \\
\text { (Videoconferencing) }\end{array}$ & Product & $\mathrm{Y}$ & $\bar{Y}$ & $\mathrm{Y}$ & $\mathrm{Y}$ & $\mathrm{Y} \mathbb{N}$ & $\mathrm{N} / \mathrm{A}^{45}$ & $\mathrm{~N} / \mathrm{A}^{46}$ \\
\hline 18 & $\begin{array}{l}\text { Hood River (PC in the family } \\
\text { room) }\end{array}$ & Product & Y & $\mathrm{N}$ & $\mathrm{N}$ & $\mathrm{N} / \mathrm{A}$ & $\mathrm{Y} \mathbb{N}$ & $\mathrm{N}$ & $\mathrm{N}$ \\
\hline
\end{tabular}

${ }^{38}$ Intel entered with Videoconferencing products. See Appendix Table II.

${ }^{39} \mathrm{~N}$ at first, $\mathrm{Y}$ later. See Appendix Table IV .

${ }^{40}$ Intel entered with some Networking products. See Appendix Table IV.

${ }^{41}$ Intel entered with some Networking products. See Burgelman (2002), 279.

${ }^{42}$ Intel entered with Chipsets and Motherboards. See Appendix Table II and Appendix Table IV.

${ }^{43}$ See Appendix Table $\mathbf{N}$.

${ }^{44} \mathrm{~N}$ at first, $\mathrm{Y}$ later. SeeAppendix Table $\mathrm{N}$.

${ }^{45} \mathrm{~N}$ at first, $\mathrm{Y}$ later. See Appendix Table $\mathrm{N}$.

${ }^{46} \mathrm{~N}$ at first, $\mathrm{Y}$ later. See Appendix Table $\mathrm{N}$. 
APPENDIX TABLE III. DRIVERS OF INTEL'S ENTRY IN COMPLEMENTARY M ARKETS 1990-2004 (CONT'D)

\begin{tabular}{|c|c|c|c|c|c|c|c|c|c|c|}
\hline & Projects & $\begin{array}{l}\text { Type of } \\
\text { Project }\end{array}$ & $\begin{array}{l}\text { Did Intel } \\
\text { believe } \\
\text { that this } \\
\text { project } \\
\text { will help } \\
\text { Job 1 } ?^{47}\end{array}$ & $\begin{array}{l}\text { Did Intel } \\
\text { believe that } \\
\text { the } \\
\text { corresponding } \\
\text { market was } \\
\text { likely to } \\
\text { directly } \\
\text { generate large } \\
\text { profits? }\end{array}$ & $\begin{array}{l}\text { Were the } \\
\text { corresponding } \\
\text { market products } \\
\text { physically } \\
\text { embodying one or } \\
\text { several interfaces - } \\
\text { i.e., was this a } \\
\text { "interface" } \\
\text { market? }\end{array}$ & $\begin{array}{l}\text { Did Intel } \\
\text { enter the } \\
\text { market? }\end{array}$ & $\begin{array}{l}\text { Did Intel } \\
\text { exit } \\
\text { later? }\end{array}$ & $\begin{array}{l}\text { Did Intel have } \\
\text { the } \\
\text { technobgical } \\
\text { and commercial } \\
\text { capabilities to } \\
\text { succeed in this } \\
\text { markets? }\end{array}$ & $\begin{array}{l}\text { Did Intel share } \\
\text { Intellectual } \\
\text { Property for low } \\
\text { royalties? }\end{array}$ & $\begin{array}{l}\text { Did Intel engage } \\
\text { in cross-industry } \\
\text { coordination, or } \\
\text { in other forms of } \\
\text { facilitation of } \\
\text { complementors' } \\
\text { innovation? }\end{array}$ \\
\hline 19 & Networking & Product & $\mathrm{N} / \mathrm{N}^{48}$ & $\mathrm{~N} / \mathrm{N}^{49}$ & $\mathrm{Y}$ & $\bar{Y}$ & $\mathrm{~N}$ & $\bar{Y}$ & $\bar{Y}$ & $\bar{Y}$ \\
\hline 20 & $\begin{array}{l}\text { Chipsets } \\
\text { (for PCI, USB, AGP, etc.) }\end{array}$ & Product & $\mathrm{Y}$ & $\mathrm{N}$ & $\mathrm{Y}$ & $\mathrm{Y}$ & $\mathrm{N}$ & $\bar{Y}$ & $\mathrm{Y}$ & $\bar{Y}$ \\
\hline 21 & $\begin{array}{l}\text { Motherboards } \\
\text { (for PCI, USB, AGP, etc.) }\end{array}$ & Product & $\mathrm{Y}$ & $\mathrm{N}$ & $\mathrm{Y}$ & $\mathrm{Y}$ & $\mathrm{N}$ & $\bar{Y}$ & $\mathrm{Y}$ & $\mathrm{Y}$ \\
\hline 22 & Software & Product & $\mathrm{Y}$ & $\mathrm{N} / \mathrm{Y}^{50}$ & $\mathrm{~N}$ & $\mathrm{~N}^{51}$ & $\mathrm{~N} / \mathrm{A}$ & $\mathrm{N}$ & $\mathrm{Y}$ & $\mathrm{Y}$ \\
\hline 23 & $\begin{array}{l}\text { Web Hosting and Online } \\
\text { services }\end{array}$ & $\begin{array}{l}\text { Consumer } \\
\text { Service }\end{array}$ & $\mathrm{N}$ & $\mathrm{Y}$ & $\mathrm{N}$ & $\mathrm{Y}$ & $\mathrm{Y}$ & $\mathrm{N}$ & $\overline{\mathrm{N}}$ & $\mathrm{N}$ \\
\hline 24 & Toys & $\begin{array}{l}\text { Consumer } \\
\text { Product }\end{array}$ & $\mathrm{N}$ & $\mathrm{Y}^{52}$ & $\mathrm{YN}$ & $\mathrm{Y}$ & $\mathrm{Y}$ & $\mathrm{N}$ & $\mathrm{N}$ & $\mathrm{Y} \mathbb{N}^{53}$ \\
\hline 25 & Audio products & $\begin{array}{l}\text { Consumer } \\
\text { Product }\end{array}$ & $\mathrm{N}$ & $\mathrm{Y}$ & $\mathrm{N}$ & $\mathrm{Y}$ & $\mathrm{Y}$ & $\mathrm{N}$ & $\bar{N}$ & $\mathrm{~N}$ \\
\hline 26 & Internet Appliances & $\begin{array}{l}\text { Consumer } \\
\text { Product }\end{array}$ & $\mathrm{N}$ & $\mathrm{Y}$ & $\mathrm{N}$ & $\bar{Y}$ & $\mathrm{Y}$ & $\mathrm{N}$ & $\mathrm{N}$ & $\mathrm{N}$ \\
\hline 27 & $\begin{array}{l}\text { Wired and Wireless handheld } \\
\text { PC Accessories }\end{array}$ & $\begin{array}{l}\text { Consumer } \\
\text { Product }\end{array}$ & $\mathrm{N}$ & $\bar{Y}$ & $\mathrm{~N}$ & $\bar{Y}$ & $\bar{Y}$ & $\mathrm{~N}$ & $\mathrm{~N}$ & $\mathrm{~N}$ \\
\hline
\end{tabular}

${ }^{47}$ I.e., Did Intel believe that this market offered strong consumption complementarities with Intel's microprocessors?

${ }^{48} \mathrm{~N}$ at first, $\mathrm{Y}$ later (after 1998). See Burgelman (2002), 279-281.

${ }^{49} \mathrm{~N}$ at first, Y later (after 1998). See Burgelman (2002), 279-281.

${ }^{50} \mathrm{~N}$ for software applications, but $\mathrm{Y}$ (at least originally) with Native Signal Processing, i.e. a software tool

$51 \mathrm{~N}$ for software applications, and N with Native Signal Processing.

$52 \mathrm{Y}$ at first, $\mathrm{N}$ later.

${ }^{53} \mathrm{Y}$ at first, $\mathrm{N}$ later. 
APPENDIX TABLE IV. IAL COORDINATION INITIATIVES IN 1997-1998

\begin{tabular}{|c|c|c|c|}
\hline IAL Initiative & Mission & Key programs & Diffusion \\
\hline $\begin{array}{l}\text { Networked } \\
\text { Multimedia }\end{array}$ & $\begin{array}{l}\text { Make multimedia pervasive on the } \\
\text { Net and provide the best experience } \\
\text { on the high-performance Connected } \\
\text { PC }\end{array}$ & $\begin{array}{l}\text { Scalable, MMX Technology } \\
\text { optimized media engines; Efficient } \\
\text { media network transports and } \\
\text { services: tools and services }\end{array}$ & $\begin{array}{l}\text { H.323 stack in Microsoft's Internet Explorer 4.0; supported by } \\
\text { firewall vendors; but also products Indeo Video 5.0; and also } \\
\text { building blocks WDE ships as part of Microsoft's Internet } \\
\text { Explorer 4.0; RSVP and RTP ship in Windows } 98 \text { and Windows } \\
\text { NT 5.0. }\end{array}$ \\
\hline Manageability & $\begin{array}{l}\text { Enable platform and network } \\
\text { infrastructure to make Intel } \\
\text { Architecture systems the most easily } \\
\text { manageable and the best managed }\end{array}$ & $\begin{array}{l}\text { Industry specifications and } \\
\text { industry groups; software } \\
\text { development kits }\end{array}$ & $\begin{array}{l}\text { Specifications, Software Development Kits; but also products: } \\
\text { Intel NIC }{ }^{54} \text { and LanDesk Software products; Also, diffused } \\
\text { through Microsoft, as ingredients: Wake -on-LAN }{ }^{55} \text { and Wake - } \\
\text { on-Ring NICs and Modems in NT, Win } 98 .\end{array}$ \\
\hline Big Pipes & $\begin{array}{l}\text { Increase content delivery capacity of } \\
\text { the connected PC to allow home and } \\
\text { business customers to easily receive } \\
\text { new broadband digital content }\end{array}$ & $\begin{array}{l}\text { Common software architecture for } \\
\text { PC broadband transport; reference } \\
\text { designs }\end{array}$ & Networking connectivity products. \\
\hline Security & $\begin{array}{l}\text { Make PC interaction trustworthy for } \\
\text { communications, commerce, and } \\
\text { content }\end{array}$ & $\begin{array}{l}\text { Industry specifications and } \\
\text { industry groups, drives the CDSA } \\
\text { standardization effort; software } \\
\text { development kits }\end{array}$ & $\begin{array}{l}\text { Open specifications and industry groups, CDSA R2.0, in } \\
\text { OpenGroup; OpenGroup standard, IBM licensed. Products also: } \\
\text { IBM and Intel shipping product based on CDSA standard. And } \\
\text { also, licenses to Zoran: DVD copy protection }\end{array}$ \\
\hline $\begin{array}{l}\text { Anywhere-in- } \\
\text { the-Home }\end{array}$ & $\begin{array}{l}\text { Unleash the potential of home PCs } \\
\text { with new uses thatdeliver computing } \\
\text { power and content when, where, and } \\
\text { how it's is needed in the home. }\end{array}$ & $\begin{array}{l}\text { PC-friendly protocols and } \\
\text { standards; concepts demos and } \\
\text { prototypes. }\end{array}$ & $\begin{array}{l}\text { Standards, Control-InfraRed - with Hewlett Packard, Microsoft, } \\
\text { and Sharp; Home - Radio-Frequency - with Compaq, IBM, and } \\
\text { HP; and Home Device Control. }\end{array}$ \\
\hline $\begin{array}{l}\text { Advance-the- } \\
\text { Platform }\end{array}$ & $\begin{array}{l}\text { Establish the media, communications, } \\
\text { and interconnect building blocks for } \\
\text { the next generation high performance } \\
\text { Intel Architecture platforms }\end{array}$ & $\begin{array}{l}\text { Interconnects USB, AGP, } 1394 \mathrm{~A} / \mathrm{B} ; \\
\text { future processor optimizations, } \\
\text { visual PC } 2000\end{array}$ & $\begin{array}{l}\text { AGP drivers, USB compliance workshops, PC-friendly 1394A } \\
\text { specifications. No commercialized products. Ingredients in } \\
\text { Microsoft's products: Reattime services in WDM in Windows } \\
98 \text { and Windows NT 5.0. }\end{array}$ \\
\hline
\end{tabular}

${ }_{54}$ NIC = Network Interface Card, an expansion board (i.e., a printed circuit board) that can be inserted into a computer so the computer can be connected to a network. Most NICs are designed for a particular type of network, protocol, and media, although some can serve multiple networks. (Source: www.webopedia.com)

${ }^{55} \mathrm{LAN}=$ Local Area Network. A computernetwork that spans a relatively small area. 